\title{
Product Action Taken Relationship
}

National Cancer Institute

\section{Source}

National Cancer Institute. Product Action Taken Relationship. NCI Thesaurus. Code

C93470.

Specifies the link between an adverse event and the steps performed with the product to address it. 